\section{Madness on trial}

\author{
Keri K. Gould
}

The Power to Harm: Mind, Medicine and Murder on Trial. By John Cornwell. Viking: 1996. Pp. 321. £18, \$24.95.

"BEHIND every crooked thought there lies a crooked molecule." This provocative soundbite is from testimony in the Fentress v. Eli Lilly and Company case. John Cornwell, a British journalist, uses the case to explain his concern with the way America's legal system and society have embraced scientific reductionist philosophy and psychopharmacological treatment to resolve individual and social dilemmas. Scientific reductionism seeks to explain human action and emotion by reducing behaviour to the molecular level, isolated from individual will and without social context. The theory removes the community from any responsibility for creating an environment supportive of antisocial behaviour.

\section{Legal drama}

Cornwell examines in depth a legal drama that at first glance appears to be about victim compensation for the tragic 1989 mass murder committed by Joseph Wesbecker, a disgruntled printing-plant employee in Louisville, Kentucky. The 12 survivors and 16 relatives of the eight deceased victims filed suit against the pharmaceutical giant Eli Lilly. (The other original defendants were eventually dropped from the case or settled out of court.) Lilly makes Prozac, the antidepressant medication Wesbecker had been taking for a month before he took an AK47 assault weapon to his former employment site and opened fire, seriously wounding or killing 20 people before killing himself.

The plaintiffs contended that Lilly was legally liable because Prozac had driven Wesbecker to commit his crime. They claimed that Lilly was negligent in making and selling Prozac because the company knew or should have known that the drug can induce violent episodes in patients with no history of violent behaviour. The plaintiffs said that the clinical tests Lilly used to persuade the federal Food and Drug Administration (FDA) that Prozac was safe to market were inadequate and the results carefully choreographed from sophisticated statistical skulduggery. It was claimed that Lilly deliberately failed to inform the FDA about serious problems with the drug. The plaintiffs' complaints also included breach of warranty and strict liability claims which asserted that the drug was unreasonably dangerous and that the company had failed to warn the public of those dangers. Lilly denied every allegation and produced voluminous testimony to defend its scien- tific trials and reporting practices.

Even when the facts of a case seem deceptively simple, the assignment of causality and blame is far more complex. In Cornwell's view, the jury was not provided with a reasoned basis for deciding liability for this tragedy. Rather, the case became a cause célébre for the vindication of a corporate pharmaceutical giant's cash cow, and a legal battle between free will and neurophilosophical reductionism. It provided the breeding ground for a secret pact and subsequent cover-up agreed to by the parties without the knowledge of the presiding judge.

At the heart of the cover-up controversy were the presiding judge's eviden-

The case became a cause célébre for the vindication of a corporate

pharmaceutical giant's cash cow, and a legal battle between free will and neurophilosophical reductionism.

tiary rulings concerning the introduction of damaging testimony on prior criminal sanctions levied against Lilly for failing to inform the FDA of deaths blamed on its drug Oraflex, an anti-arthritic medication sold in Britain before receiving US approval. After the final jury verdict of nine to three for the defendant Lilly, Judge Potter became suspicious when the plaintiffs failed to appeal. He suspected a secret settlement payoff. This was disputed by both parties, and erupted into vitriolic litigation against the judge, who sought to change the final judgment from "dismissed with prejudice" to "dismissed with prejudice as settled".

Cornwell's thorough, wide-ranging investigation of the incident, the individual and corporate entities involved and the political climate make for fascinating reading, although the sheer amount of information contained in the book and the chapter-by-chapter shifting of time, place and narrative voice can be disruptive. Reading a succinct article highlighting the facts of the incident and the procedural trial manoeuvres after I read the book gave me a better framework for appreciating the enormous amount of information assembled by Cornwell.

The book's shifting storyline dilutes the strength of the author's anger that Wesbecker's story and its exposure of the dangers of Prozac were overborne by Lilly's ability to orchestrate an enormous secret money settlement which ensured that the drug's reputation could not be sullied. The company's chutzpah was able to circumvent honest jury deliberations and promote the potential abuse of the judicial process.

Despite Cornwell's admirable research, several of the issues raised are inadequately or incorrectly explored. First, Cornwell decries the public's acceptance of increasingly intolerable workplace conditions, illustrated by Wesbecker's unrelenting harassment by the management at the printshop. His salary was cut, while it became common for him to work three or more 16-hour shifts a week in dangerous circumstances, despite medical support for his requests not to work "the folder", the most stressful and onerous task.

Facing up to the types of difficulties experienced by Wesbecker, but tragically too late to help him, the Americans with Disabilities Act was signed into law in 1990. Congress had concluded that insidious forms of discrimination against individuals with disabilities, including isolation and segregation, persist in such critical areas as employment, housing, education, health services and access to public services. Before the act, as in the case of Wesbecker, people with disabilities often had no legal recourse to obtain from an employer a reasonable recognition of their disability.

Second, the case raises important questions about the use of scientific evidence in court and the competence of judges and jurors to evaluate such evidence. Cornwell suggests that, in cases where the verdict depends on the understanding of complex scientific knowledge, judges should decide the verdict rather than juries. I think this view is misguided as it assumes judges to be more knowledgeable, less influenced by personal prejudices and better able to understand scientific data than juries .

An examination of the development of mental-disability jurisprudence indicates that judges routinely interject prejudicial viewpoints and pretextual reasoning into the decision-making process. Decision-making based on pretextuality allows judges to accept (either implicitly or explicitly) testimonial dishonesty from witnesses, especially expert witnesses, to achieve a specific end while often subordinating standards of statutory or case law. The amount of adverse media attention showered on the US judiciary, particularly in controversial cases, increases this possibility.

\section{Scientific illiteracy}

Additionally, most judges simply do not have the educational background in science to understand any better than some lay jurors the often bewildering explosion of sophisticated genetic and scientific information that lawyers are seeking to bring to court. Recognizing this chasm, the Human Genome Project has funded 
the Einstein Institute for Science, Health and the Courts to begin a national programme to educate a thousand state and federal judges in genetics and molecular biology in the next two years and to sponsor conferences in related areas.

Third, the issue of Wesbecker's legal insanity is inadequately explored in the book. Cornwell classifies the insanity defence as an "excuse" defence. He attributes its underpinnings, as well as that of several theories of mitigation, to the Durham decision which he characterizes as the rule that acquits individuals of criminal behaviour by reason of "irresistible impulse". Unfortunately, this characterization is blatantly incorrect. In fact, Durham specifically rejected both the M'Naghten good-evil test and the irresistible-impulse test by finding that a broader test is appropriate.

The Durham judgment said: "We find that as an exclusive criterion the rightwrong test is inadequate in that (a) it does not take sufficient account of psychic realities and scientific knowledge, and (b) it is based upon one symptom and so cannot validly be applied in all circumstances. We find that the 'irresistible impulse' test is also inadequate in that it gives no recogni-

ADVERTISEMENTS

Martin Dunitz Publishers

\author{
DIGHLIGHTS ED \\ Frontiers in Multiple Sclerosis \\ Abramsky \& Ovadia \\ November 1996 . \\ ISBN 1-85317-384-3 • $£ 65.00$
}

An Atlas of Malignant Haematology

Mufti, Flandrin, Schaefer, Sandberg

\& Kanfer

1996 • ISBN 1-85317-054-2 • £115.00

Cytokines and Molecular Therapy

Editors: Talpaz \& Herrmann

Quarterly journal as reviewed in Nature

Institutional: UK \& EC - £135.00;

USA \& Canada $\$ 225.00 ;$ ROW $£ 145.00$

Personal: UK \& ROW - $\$ 65.00$

USA: $\$ 99.00$

Martin Dunitz Publishers has extensive current and forthcoming

lists in the following areas:

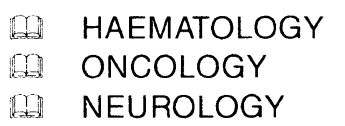

\section{$\overline{\text { MARTIN The Livery House }}$ DUNITZ 2 -9 Pratt Street DUNITZ Tel: 01714822202 PUBLISHING Fax: 01714827088}

Scientific publisher of

medical books and journals tion to mental illness to the application of the inadequate right-wrong test. We conclude that a broader test should be adopted."

Durham predicates the lack of criminal responsibility on a finding that the "unlawful act is the product of mental disease or defect". Durham came under rigorous criticism for being too heavily dependent on medical expertise and was overruled in 1972. US v. Brawner, which overruled Durham, added a volitional component to M'Naghten's cognitive inquiry. The Brawner test holds that defendants are not responsible for their criminal conduct if, as a result of mental disease or defect, they "lacked substantial capacity either to appreciate the criminality of their conduct or to conform their conduct to the requirements of law".

Kentucky law offers both a "not guilty by reason of insanity" (NGRI) verdict and a "guilty but mentally ill" (GBMI) verdict. About a third of the jurisdictions in the United States do likewise. Under GBMI, a person may be found guilty of the crime and mentally ill, but not legally insane at the time of the offence. People convicted under such a statute are sentenced to prison with the caveat that they are mentally ill and should receive treatment during their incarceration. The far more interesting question, not raised in the book, is whether Wesbecker would have been able successfully to use the insanity defence had he lived, and what impact, if any, an NGRI or GBMI verdict would have had on the subsequent civil proceedings.

Cornwell warns of the potential apocalypse created by "the growing crisis over reductionist solutions to individual suffering and social disorder". As society increasingly turns from social solutions to pharmacological quick-fixes, Cornwell foresees dire consequences. But he closes the book with hopeful musings on the enduring power of social solutions and leaves his readers to ponder the imperfect relationships between mind, medicine and murder.

Keri K. Gould is at the School of Law, Fordham University, 140 West 62nd Street, New York, New York 10023, USA.

\section{When litigation becomes a lottery}

\section{Lee Loevinger}

Science on Trial: The Clash of Medical Science and the Law in the Breast Implant Case. By Marcia Angell. Norton: 1996. Pp. 256. \$27.50, £22. Published in the United Kingdom in January 1997.

MARCIA Angell, executive editor of the New England Journal of Medicine, considers herself a feminist and a liberal Democrat but, above all, a scientist. She had no particular interest in silicone breast implants until the journal published two articles on the subject that indicated a discrepancy between the law and the scientific evidence.

By 1992, implants had been on the market for 30 years, between 1 million and 2 million women had them, and more than 90 per cent were pleased with them. But in April that year, David Kessler, commissioner of the US Food and Drug Administration (FDA), announced a virtual ban. At that time there was no scientific evidence that implants caused disease, but women panicked, and lawyers filed more than 30,000 suits against implant manufacturers.

In April 1994 a proposed settlement was approved in a class action that provided US $\$ 4.25$ billion to settle all claims. That sum included $\$ 1$ billion for lawyers' fees. The settlement provided for payment unconditionally to any woman who had received an implant without any signs of illness or other conditions caused by it. Advertisements inviting women to file claims appeared throughout the United States in newspapers and on television and radio.

In June 1994 the journal published the first epidemiological study of breast implants, and it found no association with disease. But by May 1995 more than 400,000 women had filed claims, Dow Corning, the principal defendant, was overwhelmed by the number of lawsuits and filed for bankruptcy, and the proposed settlement fell apart. Angell was struck by the discrepancy between the legal proceedings and the scientific evidence, and decided to write this book.

Although hooked on the apparent conflict between science and law, Angell is no zealot. She defends the function of the FDA while questioning, rather than condemning, the implant ban. She reports epidemiological studies done after 1994, and lucidly explains the relevance of the statistics, which continue to show no apparent connection between implants and disease.

What she "was not prepared to find was the extent of the financial involvement" of plaintiffs' lawyers, the complicity of some physicians, and cases resulting in relatively small gains for many women but enormous gains for a few lawyers.

The breast implant story also illustrates how subpoenas can be used to harass and intimidate scientists. The authors of breast implant studies have 